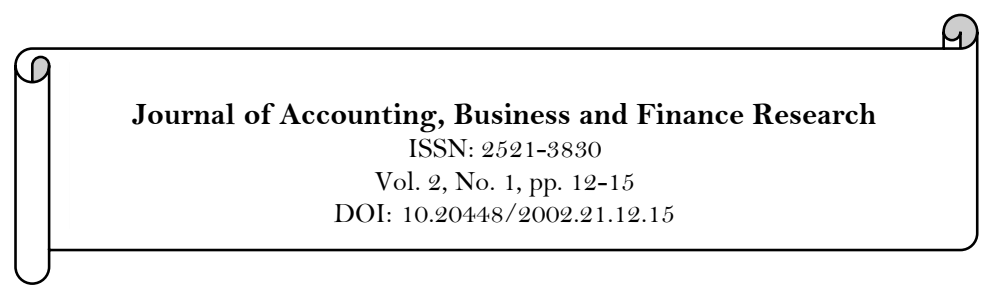

\title{
Effect of Lifestyle on Consumer Decision Making: A Study of Women Consumer of Pakistan
}

\author{
Zaeema Asrar Mohiuddin ${ }^{1}$
}

${ }^{1}$ Assistant Professor, Department of Commerce University of Karachi, Karachi, Pakistan

\begin{tabular}{|c|c|}
\hline Abstract & \\
\hline $\begin{array}{l}\text { To develop the understanding of consumer behavior is considered as an } \\
\text { important element for the producers and marketing managers. The } \\
\text { buying behavior of consumers is highly dependent on their lifestyle. } \\
\text { This research strives to examine the effect of lifestyle on the female } \\
\text { buying decisions. For this reason, } 150 \text { close ended questionnaires were } \\
\text { distributed among the female buyers of Karachi followed by convenient } \\
\text { sampling approach. Out of } 150,120 \text { questionnaires were received for the } \\
\text { further analysis. The sample portrays that majority of the women belong } \\
\text { from the upper middle class. Most of them are working women and } \\
\text { students and belong from the age group of } 18 \text { years to } 50 \text { years. The } \\
\text { findings of the study highlights that majority of the women prefer to } \\
\text { buy imported brands rather than local ones. In line with this, they } \\
\text { prefer to go through the reviews regarding the newly launched brand } \\
\text { before making any purchase. With respect to the findings, it is } \\
\text { recommended that local producers should improve their quality so that } \\
\text { they can capture the large market of female buyers. }\end{array}$ & $\begin{array}{l}\text { Keywords: } \\
\text { Lifestyle } \\
\text { Decision Making } \\
\text { Women } \\
\text { Buying } \\
\text { Brands. } \\
\text { Licensed: } \\
\text { This work is licensed under a } \\
\text { Creative Commons Attribution } \\
\text { 4.0 License. } \\
\text { Publisher: } \\
\text { Scientific Publishing Institute }\end{array}$ \\
\hline
\end{tabular}

\section{Introduction}

The study of consumer behavior always has a significant importance for the managers of marketing. Since the success of business depends on the consumers' buying decisions towards product. To comprehend the behavior of consumers, managers have to develop the understanding regarding their adopted life style. The standard of living has a significant impact on the consumers' mindset and its overall potential of purchasing (Cherian \& Jacob, 2012). According to Hernández, Jiménez, and Martín (2010) lifestyle is based on the standard of living that explains the people's purchasing power. Moreover, Young, Hwang, McDonald, and Oates (2010) presents a broad definition of lifestyle. According to him, lifestyle is based on the people's thinking, beliefs and attitude towards the society. These attitudes, mindsets and beliefs put significant impact on the decisions taken by people whether these decisions are related to their personal life or professional life. The day to day decisions are also affected by the lifestyle. Therefore, it is an important aspect for the marketing managers to analyse the life style of the consumers of targeted market for the successful product marketing that enhance their likelihood of increased volume of sales. It is mentioned by Solomon, RussellBennett, and Previte (2012) are exist a difference between male and female attitudes and buying behavior. The lifestyle of women is transforming due to the transformation in modern technology that affect the daily matters and events. In this era, majority of women are associated to the labor force and works fulltime in the corporate sector. It is found by the study of Handa and Khare (2013) female consumers prefer trendy products rather than their male counterparts. For this reason, producers have to consider the likeness of the female consumers to sustain in the market with high-end competition. Especially Pakistan is observing this transformation of lifestyle these days. In addition to this, the population of female is increasing rapidly than male. According to World Bank (2015) female population in Pakistan is around 49 percent of all the population. The increasing ratio of female workforce has great impact on their attitudes and purchasing decisions. Therefore, the objective of the present study is to explore the impact of lifestyle on the decision making of female consumer of Pakistan. 


\section{Literature Review}

Various authors have shed light on the importance of the women's purchase decision making that is highly affected by their lifestyle. According to Van Doorn et al. (2010) marketing managers are required to understand the buying behavior of female customer so that they can enhance their profit. It is imperative to understand the buying behavior of female customers because their purchase decisions are based on their lifestyle that includes their social status, likeness and ongoing fashion trend. The study by Jensen (2012) the purchase decision of women highly affects the purchase decision of all over the household because in majority of the household women purchase the grocery items, clothes and other accessories for the other members of the household. It is mentioned by Rani (2014) numerous factors affect the lifestyle of the customers' especially female customers such as demographic elements, aims, beliefs, values, the environment of the household and so on. The necessities and the preferences of the customer are highlighting dependent on the different elements of the lifestyle. Many studies highlight that the purchase attitude varies from the nature of purchase such as food, clothes, automobile, and other expensive items [(Douglas \& Samuel Craig, 2011; Majumdar, 2010; Thøgersen, de Barcellos, Perin, \& Zhou, 2015)]. It is mentioned by Workman and Lee (2011) women are more concerned about their personality and physical appearance therefore they are more inclined towards the purchase of branded clothes and makeup. Even the women from middle class households save money to buy good quality clothes, makeup, jewelry and other accessories. In line with this, it is mentioned by Dennis, Morgan, Wright, and Jayawardhena (2010) women usually prefer to buy trendy and stylish items according to the ongoing fashion. Therefore, to capture the attention of female buyer, marketing managers have to keep this factor in mind too. It is suggested by Lin, Chen, and Kuan-Shun (2010) the producers must study the lifestyle of the customers of the targeted market. In the similar notion, it is asserted by Kotler (2012) if the products are being made according to the demand and preferences of the customers, there is strong likelihood of increased the profit in present as well in the future Because a satisfied and happy customer is a real asset of the company. According to Qing, Lobo, and Chongguang (2012) there is difference between lifestyle of the customers who belong from the metropolitan areas and slum areas of the country. The marketing managers have to segment the market based on the regions and ethnicities. In line with this, it is highlighted by Sharma and Lal (2012) the demographic factors such as age, income, marital status and religion have the significant impact of lifestyle and these elements collectively affect the buying behavior of female customers.

Various examines have turned out with the conclusion that buyers were affected by the movement expenses of shopping and store site thus assumes an essential part in the store decision (Freymann, 2002). Life-style promoting and promoting have progressively come to command how retailers moved toward clothing, and this has effectively affected how denim was offered to various target markets with various way of life introductions. Babin and Babin (2001) found that in stores Consumer's acquiring expectations and spending can to a great extent be impacted by feelings. These feelings might be particular to specific things like the highlights of the things, client self-intrigue, buyer's measure of assessing things and the significance they provided for their obtaining at a store. Kavak and Gumusluoglu (2007) deduced in their investigation that religiosity had an effect on shopper ethnocentrism and that as Turkish purchasers turn out to be greater group arranged, they had a tendency to end up noticeably more ethnocentric, though as they turned out to be more authority situated they turn out to be less ethnocentric. Kesic and Piri-Rajh (2003) considered the Croatian populace and separated it into segments by the way of life with respect to nourishment and its propensities. The examination inferred that Croatian public incorporates five ways of life for the work of art, today, genuine, and liberal and hopeful. As indicated by a research by Kim (2003) lifestyle, as it influenced numerous parts of a consumers' behavior, similarly influenced the decisions of the elderly with respect to which sort of lodging they would rather incline toward.

Lifestyle segmentation was very important not only to study consumer behavior in common however it is also very significant in worldwide marketing owing to its huge impact on the day by day purchasing choices by each individual. A research performed by Kavak and Gumusluoglu (2007) in the capital of Ankara, Turkey, recognized thirteen lifestyle scopes. Additionally, price perception and ethnocentrism have been found to be optimistically linked. Andersone and Gaile-Sarkane (2009) consumer behavioral features prejudiced the life style factors and their role in consumer behavior.

\section{Research Method}

This section strives to explore the research objective of the present study empirically. To examine the impact of lifestyle of the female consumer on their buying behavior, primary data have been collected. For the purpose of data collection, 150 close ended questionnaires were distributed among the female buyers of Karachi followed by convenient sampling approach. Out of 150, 120 questionnaires were received for the further analysis. The responses were measured by the Likert Scale technique. For the statistical analysis, percentage method was employed using MS- Excel (2016). 


\section{Results and Discussion}

The collected sample portrays that majority of the women belong from the upper middle class. Most of them are working women and students and belong from the age group of 18 years to 50 years. The data indicate that majority of the women (68\%) prefer to buy branded products whether the products belong from eatables, clothes or cosmetic. On the other hand, the other research participants prefer to grab clothes and other accessories from sales on discounted prices. This finding is consistent with the study of Dennis et al. (2010) majority of the female buyers are prone towards the brand and they fall in the category of brand conscious people. Therefore, they mostly prefer to have branded articles and attires. In line with this, 52 percent female buy products from the online pages and enjoy online shopping because they get their desired product at their door step Whereas 40 percent women do not prefer online shopping due to their past bad experiences of online shopping. 20 percent women spend all of their savings while purchasing branded items whereas other women think about tomorrow and spend with care. In addition to this, when women were asked that if they prefer to get the advice before making any purchase from the newly introduced brands. The data shows that 65 percent women are strongly agree with this statement. They prefer to go through the reviews regarding the newly launched brand before making any purchase. In line with this, the data depicts that there are mixed responses regarding the preference of local and imported items. 49 percent female buyers prefer to buy imported brands with the local brands also. On the other hand, 51 percent female buyers prefer to use drug store cosmetic and clothes, shoes and bags from the local brands.

Consumer's lifestyle is inclined by demographic characteristics and morals and consumer's lifestyles do influence their apparent illustration of a store. Life styles are a demonstration of an individual's self-concept. It is the total image one has of him or herself, Lifestyles fabricate wants and desires that eventually influence the verdict of each consumer, even the feelings and emotions are very important in consumer purchase decisions and exert consequences on the analysis of commodity attributes.

Social status is one of the key components to how and why individuals purchase certain good and services. It influences the quality and amount of what individuals purchase (Boundless.com, n.d). The rich have more money to spend on higher quality goods, Tanner and Raymond (2012). Though the lower class will concentrate more on necessities and concentrate on getting one pleasant outfit, yet then spend more on nourishment and their home.

Individuals' life style becomes an integral factor particularly when they come to high contribution commodities. These commodities convey high hazard, are mind boggling or have high sticker prices. Friesner (2014). Lifestyle is a vital perspective when looking at consumers' decisions. Because there might be two women with comparable age and wage, does not mean they're probably going to buy similar product (Hickey, Nader, \& Williams, 2012).

Self image is a strong viewpoint when pondering how lifestyle influences purchases (Schiffman, 2014). The way somebody feels they should look will clearly influence what they purchase. There are such huge numbers of elements which can impact people groups purchasing propensities, and lifestyle is certainly a significant one. How individuals need to look blended with the measure of ages they acquire, characterizes how their way of spending habit form.

\section{Conclusion}

The lifestyle is an important factor that affect the buying behavior of the customers specially behavior of women. Lifestyle is a combination of different factors such as demographic, religion and cultural. There are several elements that significantly affect the female buying behaviors. Therefore, it is imperative to understand for the producers regarding the lifestyle of the consumers. The aim of the present study is to analyze the buying behavior of women that is affected by their lifestyle. The findings indicate that majority of the women most of the women prefer to buy imported branded products whether the products belong from eatables, clothes or cosmetic. Moreover, 52 percent female buy products from the online pages and enjoy online shopping whereas other women buyer do not prefer to purchase from online pages and websites due to past bad experiences. Under the light of findings, it is suggested that local producers should improve their quality standards so that they can capture the large market of female buyers. Furthermore, the Pakistani producers should study the consumers' preferences and their requirements well to attract them towards local brands.

\section{References}

Andersone, \& Gaile-Sarkane. (2009). Factors influencing online shopper behaviour. International Journal of Online Marketing, 5 .

Babin, \& Babin. (2001). Research on variety seeking and customer satisfaction. International Journal of Marketing Studies, 3. Boundless.com. (n.d). Social class.

Cherian, J., \& Jacob, J. (2012). Green marketing: A study of consumers' attitude towards environment friendly products. Asían Social Science, 8(12), 117-126. 
Dennis, C., Morgan, A., Wright, L. T., \& Jayawardhena, C. (2010). The influences of social e-shopping in enhancing young women's online shopping behaviour. Journal of Customer Behaviour, 9(2), 151-174.

Douglas, S. P., \& Samuel Craig, C. (2011). The role of context in assessing international marketing opportunities. International Marketing Review, 28(2), 150-162.

Freymann. (2002). Life style marketing and merchandising: Research Publications.

Friesner, T. (2014). Consumer behavior: Internal influences. Retrieved from: http://www.marketingteacher.com/internalinfluences-lifestyle-and-attitude/. [Accessed 7/5/2015].

Handa, M., \& Khare, A. (2013). Gender as a moderator of the relationship between materialism and fashion clothing involvement among Indian youth. International Journal of Consumer Studies, 37(1), 112-120.

Hernández, B., Jiménez, J., \& Martín, M. J. (2010). Customer behavior in electronic commerce: The moderating effect of epurchasing experience. Journal of Business Research, 63(9-10), 964-971.

Hickey, M., Nader, T., \& Williams, T. (2012). Influences on marketing.

Jensen, R. (2012). Do labor market opportunities affect young women's work and family decisions? Experimental evidence from India. The Quarterly Journal of Economics, 127(2), 753-792.

Kavak, B., \& Gumusluoglu, L. (2007). Segmenting food markets-the role of ethnocentrism and lifestyle in understanding purchasing intentions. International Journal of Market Research, 49(1), 71-94.

Kesic, T., \& Piri-Rajh, S. (2003). Market segmentation on the basis of food-related lifestyles of Croatian families. British Food Journal, 105(3), 162-174.

Kim. (2003). Elsevier-lifestyle analysis: A dimension for future-oriented bank research. Journal of Bank Research.

Kotler, P. (2012). Kotler on marketing: Simon and Schuster.

Lin, R. J., Chen, R. H., \& Kuan-Shun, C. K. (2010). Customer relationship management and innovation capability: An empirical study. Industrial Management \& Data Systems, $110(1), 111-133$.

Majumdar, R. (2010). Consumer behaviour: Insights from Indian market: PHI Learning Pvt. Ltd.

Qing, P., Lobo, A., \& Chongguang, L. (2012). The impact of lifestyle and ethnocentrism on consumers' purchase intentions of fresh fruit in China. Journal of Consumer Marketing, 29(1), 43-51.

Rani, P. (2014). Factors influencing consumer behaviour. International Journal of Current Research and Academic Revierw, 2(9), $52-61$.

Schiffman, L. (2014). Consumer behaviour. Australia: Pearson Group.

Sharma, S., \& Lal, K. (2012). Changing consumer behaviour-A challenge for sustainable business growth. International Journal of Marketing, Financial Services ङं Management Research, 1(8), 149-158.

Solomon, M., Russell-Bennett, R., \& Previte, J. (2012). Consumer behaviour: Pearson Higher Education AU.

Tanner, J., \& Raymond, M. (2012). Marketing principles: Consumer behaviour- how people make buying decisions, creative commons.

Thøgersen, J., de Barcellos, M. D., Perin, M. G., \& Zhou, Y. (2015). Consumer buying motives and attitudes towards organic food in two emerging markets: China and Brazil. International Marketing Review, 32(3/4), 389-413.

Van Doorn, J., Lemon, K. N., Mittal, V., Nass, S., Pick, D., Pirner, P., \& Verhoef, P. C. (2010). Customer engagement behavior: Theoretical foundations and research directions. Journal of Service Research, 13(3), 253-266.

Workman, J. E., \& Lee, S. H. (2011). Vanity and public self-consciousness: A comparison of fashion consumer groups and gender. International Journal of Consumer Studies, 35(3), 307-315.

Young, W., Hwang, K., McDonald, S., \& Oates, C. J. (2010). Sustainable consumption: Green consumer behaviour when purchasing products. Sustainable Development, 18(1), 20-31. 